MACIEJ GURTOWSKI

ORCID: 0000-0002-2990-9088

Centrum Badań nad Bezpieczeństwem

Akademia Sztuki Wojennej

m.gurtowski@akademia.mil.pl

\title{
Cyfrowy wyścig zbrojeń w erze ekspansji kapitalizmu nadzoru
}

https://doi.org/10.19195/2083-7763.10.9

Abstrakt

Amerykańska psycholog społeczna Shoshana Zuboff w swojej najnowszej książce The Age of Surveillance Capitalism nakreśliła kompleksową teorię tłumaczącą przemiany współczesnego kapitalizmu. Nazwała go „kapitalizmem nadzoru”, wskazując na kluczową rolę przemian w zakresie narzędzi kontroli społecznej. Celem niniejszego referatu jest uzupełnienie koncepcji „kapitalizmu nadzoru" o wymiar wpływu opisywanych przez Zuboff procesów na sferę bezpieczeństwa. Rozważona zostanie hipoteza, że tak jak kapitalizm przemysłowy określał warunki brzegowe zimnowojennego wyścigu zbrojeń, tak samo kapitalizm nadzoru Zuboff z koncepcji można interpretować jako koło zamachowe procesu cyfrowego wyścigu zbrojeń.

Słowa kluczowe: bezpieczeństwo militarne, bezpieczeństwo ontologiczne, cyfrowy wyścig zbrojeń, kapitalizm nadzoru, kapitalizm przemysłowy, kompleks militarno-przemysłowy, kryzys, osoba ludzka

\section{Cyfrowy wyścig zbrojeń w erze ekspansji kapitalizmu nadzoru}

W niniejszym artykule zostanie podjęta próba wskazania i rozważenia struktury pojęciowej, która ma przybliżyć do trafnego uchwycenia jednego z kluczowych mechanizmów dynamiki współczesnego świata. W tym celu zrekonstruowana zostanie koncepcja kapitalizmu nadzoru Shoshany Zuboff. Przejściu od klasycznie pojmowanego kapitalizmu przemysłowego do kapitalizmu nadzoru towarzyszą przemiany w globalnej strukturze bezpieczeństwa, które autorka koncepcji 
kapitalizmu nadzoru porusza, ale szerzej ich nie analizuje ${ }^{1}$. Celem niniejszego artykułu jest rozwinięcie tego wątku.

\section{Hipoteza i metoda badawcza}

Do realizacji tegoż celu posłuży metoda analizy porównawczej w jej zamkniętej wersji, w której porównywane przypadki zostały dobrane celowo przed rozpoczęciem czynności analitycznych ${ }^{2}$. Zestawienie z sobą porównywanych przypadków ma pomóc w lepszym określeniu ich podobieństw i różnic, charakterystycznych cech i relacji między nimi. Tak rozumiana metoda analizy porównawczej skupia się na dążeniu do stwierdzenia występowania lub braku albo ustalenia stopnia nasilenia określonych cech jakościowych w wybranych obiektach.

Prezentowana i rozważana w niniejszym artykule hipoteza jest następująca: walczące o bezpieczeństwo i dominację na arenie międzynarodowej podmioty, dążąc do uzyskania przewagi technologicznej, uruchomiły dynamikę cyfrowego wyścigu zbrojeń ${ }^{3}$, która zagraża bezpieczeństwu ontologicznemu (w sensie A. Giddensa) społeczeństw, które wyścig ten obejmuje.

\section{Kapitalizm nadzoru}

Kapitalizm nadzoru ${ }^{4}$ (ang. surveillance capitalism, tłumaczony także na język

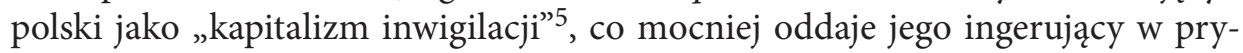
watność charakter) to koncepcja autorstwa prof. Shoszany Zuboff, amerykańskiej psycholog z Uniwersytetu Harvardzkiego. Autorka w nieco encyklopedycznej, lapidarnej manierze definiuje go jako:

1. Nowy system ekonomiczny, w którym doświadczenia ludzi uznano za swobodnie dostępny, surowy materiał, używany do prowadzonych w ukryciu działań komercyjnych w postaci jego ekstrakcji, predykcji i sprzedaży; 2. Pasożytnicza logika ekonomiczna w której produkcja dóbr i usług podporządkowana jest nowej globalnej architekturze bazującej na modyfikacji zachowań

${ }^{1}$ S. Zuboff, The Age of Surveillance Capitalism. The Fight for the Future at the New Frontier of Power, Londyn 2019, s. 116-119.

${ }^{2}$ K. Konecki, Studia z metodologii badań jakościowych. Teoria ugruntowana, Warszawa 2000, s. $60-61$.

3 A. Craig, B. Valeriano, Conceptualising cyber arms races, 8th International Conference on Cyber Conflict (CyCon), 2016, https://ieeexplore.ieee.org/abstract/document/7529432 (dostęp: 12.04.2019); M. Taddeo, L. Floridi, Regulate artificial intelligence to avert cyber arms race, „Nature”, 16.04.2019, s. 296, https://www.nature.com/articles/d41586-018-04602-6?platform=hootsuite (dostęp: 12.04.2019).

4 S. Zuboff, op. cit.

5 E. Sarnacka-Mahoney, Kapitalizm inwigilacji. Nasze zachowanie jest już nie tylko śledzone, ale też zmieniane $w$ określonym kierunku. Wywiad z Shoshana Zuboff, 7.07.2018, https://forsal.pl/ artykuly/1164703,kapitalizm-inwigilacji-nasze-zachowanie-jest-juz-nie-tylko-sledzone-ale-tez-zmieniane-w-okreslonym-kierunku-wywiad.html (dostęp: 12.04.2019).

Forum Socjologiczne 10, 2020

(C) for this edition by CNS 
ludzi; 3. Łupieżcza odmiana kapitalizmu odznaczająca się bezprecedensową w historii koncentracją bogactwa, wiedzy i władzy; 4. Podstawowa rama ekonomii inwigilacji; 5. Znaczące zagrożenie dla ludzkiej natury w XXI wieku, takie, jakie stanowił kapitalizm przemysłowy dla środowiska naturalnego w wieku XIX; 6 . Wyłanianie się nowej władzy o instrumentalnym charakterze zapewniającej dominację nad społeczeństwem i stanowiącej wyzwanie dla demokracji rynkowej; 7. Ruch, którego celem jest narzucenie nowego porządku społecznego opartego na totalnej przewidywalności; 8 . Wywłaszczenie z podstawowych praw człowieka, rozumiane jako odgórnie przeprowadzony zamach na nie: przewrót w zakresie ludzkiej suwerenności ${ }^{6}$.

Początki kapitalizmu nadzoru to według Zuboff rok 2004. Wtedy to jej zdaniem firma Google w końcu wypracowała rewolucyjny model monetyzacji swojej wyszukiwarki ${ }^{7}$. Do tej pory Google, dysponując wysokiej jakości wyszukiwarką internetową, nie miał dobrego pomysłu, w jaki sposób ma ona generować zysk. Rozważano między innymi wprowadzenie opłat za korzystanie z niej lub umieszczanie na stronie głównej reklam. Nowy pomysł polegał na zbieraniu informacji o korzystających z wyszukiwarki, analizowaniu ich, a następnie sprzedawaniu ich reklamodawcom. Zuboff do wyjaśnienia tego podejścia używa obrazowego porównania, pisząc, że „ludzie używają wyszukiwarki, aby się czegoś dowiedzieć, gdy tymczasem to wyszukiwarka dowiaduje się czegoś o ludziach"8. Z czegoś, co jawiło się wcześniej jako „produkt uboczny” działania wyszukiwarki, uczyniono główne źródło przychodów ${ }^{9}$. Dzięki lepszej wiedzy o konsumentach sprzedawcy i reklamodawcy mogą zmniejszyć niepewność związaną z nietrafnym rozpoznaniem popytu na produkt. Według Zuboff model ten zrewolucjonizował współczesny kapitalizm i staje się obecnie pewnym standardem, redukując znaczenie klasycznego marketingu.

Głównym zasobem generującym wartość w kapitalizmie nadzoru jest w koncepcji Zuboff tak zwana nadwyżka z kontroli zachowań (behavioral surplus) ${ }^{10}$. Składa się na nią seria śladów pozostawianych przez użytkownika podłączonych do sieci urządzeń, na podstawie których można uzyskać cenną wiedzę o jego stylu życia, modelu konsumpcji, potrzebach i marzeniach, a także można dokonywać trafnych przewidywań o jego zachowaniach $\mathrm{w}$ przyszłości ${ }^{11}$. Behavioral suplus jest przy tym, w przeciwieństwie do na przykład złota czy ropy, zasobem praktycznie niewyczerpywalnym i niemal bezkosztowym ${ }^{12}$. To użytkownicy różnych

\footnotetext{
${ }^{6}$ S. Zuboff, op. cit., s. I.

7 Ibidem, s. 65, 78-81.

8 Ibidem, s. 68, 262.

9 Ibidem, s. 67-68.

10 Ibidem, s. 81.
}

11 W literaturze przedmiotu obraz człowieka zbudowany na ich podstawie określa się mianem „cyfrowego sobowtóra”, zob. M. Gurtowski, J. Waszewski, Prejudices behind Algorithms: Automated Surveillance Systems as Tools of Segregation and Discrimination, „Kultura i Edukacja” 2018, nr 4; J. Waszewski, M. Gurtowski, Cyfrowy rasizm? Zautomatyzowane techniki nadzoru jako narzędzie segregacji i dyskryminacji, „Transformacje” 2015, nr 1/2.

12 S. Zuboff, op. cit., s. 107.

Forum Socjologiczne 10, 2020

(C) for this edition by CNS 
podpiętych do sieci urządzeń dostarczają nadwyżki z kontroli zachowań przy okazji załatwiania swoich codziennych potrzeb. Bazy danych zasilane codziennie przez miliardy użytkowników stają się przez to zasobem o ciągle rosnącej wartości, ponieważ rośnie ich potencjał predykcyjny.

Zdaniem Zuboff korzystanie przez ludzi na co dzień z połączonych do sieci urządzeń sprawia, że całe ich życie zaczyna stawać się przeszukiwalne ${ }^{13}$. Na podstawie danych z czyjegoś telefonu można bardzo dokładnie odtworzyć czyjeś życie: gdzie i o której godzinie przebywał, co robił, jak się czuł, co zresztą bywa już praktycznie wykorzystywane - dane z telefonu mogą być bowiem użyte jako dowód w sądzie, dostarczając na przykład alibi.

Według Zuboff można zaobserwować swoisty zespół wyparcia oraz próby racjonalizacji odzierania nas z prywatności. Jej zdaniem zwłaszcza osoby z młodszego pokolenia coraz częściej nie widzą niczego złego w tym, że wielkie i mniejsze korporacje permanentnie zbierają informacje o wszystkich szczegółach ich życia. Amerykańska psycholog krytykuje taką postawę, wskazując, że prywatność rozumiana jako prawo i jako zdolność do podejmowania działań poza radarem kontroli innych ludzi pełni bardzo ważne funkcje psychologiczne. Przyczynia się ona do zachowania mentalnej równowagi i stabilności tożsamości. Zuboff podsumowuje ten wątek, stwierdzając dobitnie, że „jeśli nie masz nic do ukrycia - jesteś nikim”14.

Zuboff twierdzi, że rozwój technologii kapitalizmu nadzoru sprawia, że już nie tylko analizuje się zachowania ludzi, lecz zaczyna się także je kreować ${ }^{15}$. Przykładem są urządzenia modyfikujące zachowania ludzi, na przykład opaski smart, które dyktują użytkownikom, ile mają zrobić kroków i kiedy pójść spać, lub gry typu Pokemon Go, które wabią użytkowników w kierunku, w którym znajdują się lokale popularnych sieci restauracji fastfood czy kawiarni ${ }^{16}$. Zdaniem autorki trend ten będzie przybierał na sile wraz z ekspansją urządzeń Internetu Rzeczy. Będą nam one „grały do tańca”, dyktując, co i kiedy mamy robić, akurat w takt zgodny $\mathrm{z}$ interesem kapitalistów nadzoru ${ }^{17}$. Inteligentna lodówka będzie decydować o naszej diecie, a autonomiczny samochód dbał o nasze bezpieczeństwo na drodze. Konsekwencją będzie stopniowa utrata autonomii przez człowieka ${ }^{18}$ i problemy z autokreacją ${ }^{19}$. Zachowania ludzi staną się coraz bardziej przewidywalne, a przecież, jak stwierdza Zuboff, „nie ma wolności bez niepewności”20. Kapitaliści nadzoru zdobywają władzę nie dzięki posiadaniu środków produkcji, ale dzięki kontroli mechanizmów modyfikacji zachowań ludzi ${ }^{21}$.

\footnotetext{
13 Ibidem, s. 98.

14 Ibidem, s. 479.

15 Ibidem, s. 9.

16 Ibidem, s. 150.

17 Ibidem, s. 293.

18 Ibidem, s. 262.

19 Ibidem, s. 456.

20 Ibidem, s. 333.

21 Ibidem, s. 379.
} 
Rutynowe korzystanie z urządzeń smart w realizacji kolejnych życiowych potrzeb powoduje, że człowiek staje się coraz bardziej zewnątrzsterowny ${ }^{22}$, powoli zatraca swoją zdolność do bycia podmiotem, do wyznaczania sobie celów i sposobów ich realizacji. W zamian za to podmioty zależne od kapitalistów nadzoru będą nam dyktować, jak i z kim mamy się komunikować (media społecznościowe), czego możemy się dowiedzieć o świecie i o samych sobie (wyszukiwarka internetowa), a nawet jak i z kim mamy nawiązywać relacje intymne (aplikacje typu Tinder). Efektem opisywanego tu procesu będzie podważenie jednego $\mathrm{z}$ fundamentów współczesnej cywilizacji Zachodu (możemy nazwać ją także judeo-chrześcijańską), czyli wolności indywidualnej człowieka.

Zuboff zdaje sobie sprawę, że wiedza zdobywana dzięki analizie „nadwyżki z kontroli zachowań" ma nie tylko wartość rynkową, ale także militarną ${ }^{23}$, dając potencjalny wgląd w szczegóły życia przeciwnika oraz własnej armii. Jednakże autorka wątku tego nie pogłębia. $\mathrm{Z}$ wywodu Zuboff wynika, że ten, kto posiądzie lepsze narzędzia właściwe kapitalizmowi nadzoru, czyli analizy, przewidywania i modyfikacji zachowań ludzi, ten zyska bezprecedensowe narzędzia kontroli całych społeczeństw. Trudno o lepszy przykład technologii podwójnego zastosowania umożliwiającej (w duchu Sun $\mathrm{Tzu}^{24}$ ) wygrywanie wojen bez toczenia bitew.

\section{W stronę cyfrowego wyścigu zbrojeń}

Proponuję przyjąć, że Zuboff trafnie opisuje istotne makrotrendy w dziedzinie gospodarczej, technologicznej i ogólnocywilizacyjnej ${ }^{25}$. Chciałbym odnieść je także do sfery bezpieczeństwa, posługując się analogią między klasycznym kapitalizmem przemysłowym, w ramach którego miał miejsce zimnowojenny wyścig zbrojeń, a kapitalizmem nadzoru, który wyznacza ramy cyfrowego wyścigu zbrojeń ${ }^{26}$.

Tak jak w klasycznym zimnowojennym wyścigu zbrojeń procesowi temu towarzyszyło uformowanie się kompleksu militarno-przemysłowego (w sensie nadanym

22 W sensie, który zewnątrzsterowności nadał D. Riesman, Samotny tłum, przeł. J. Strzelecki, Warszawa 1971, s. 30.

${ }^{23}$ Ibidem, s. 243, 385.

24 S. Tzu, Sztuka wojny, przeł. M. Bugajska, Warszawa 2009.

25 Choć należy mieć świadomość błędów i uproszczeń jej koncepcji, spośród których warto wskazać w szczególności na etnocentryzm czy też amerykanocentryzm perspektywy. Zuboff rozciąga na cały świat generalizacje opisywane przez nią na podstawie obserwacji zjawisk z USA, gdy tymczasem umyka jej, że niemal połowa ludności świata wciąż pozbawiona jest dostępu do sieci, zob. United Nations, Internet milestone reached, as more than 50 per cent go online: UN telecoms agency, 7.12.2018, https://news.un.org/en/story/2018/12/1027991 (dostęp: 1.09.2019); szerzej na temat krytyki Zuboff zob. E. Morozov, Capitalism's New Clothes, „The Baffler”, 4.02.2019, https://thebaffler.com/ latest/capitalisms-new-clothes-morozov (dostęp: 1.09.2019).

${ }^{26} \mathrm{Na}$ analogię tę zwrócił uwagę Andrzej Zybertowicz w wykładzie wygłoszonym na III Kongresie Elektryki Polskiej w Warszawie 2 kwietnia 2019.

Forum Socjologiczne 10, 2020

(C) for this edition by CNS 
temu pojęciu przez C.W. Millsa ${ }^{27}$ ), tak samo na skutek cyfrowego wyścigu zbrojeń mówi się o powstaniu kompleksu przemysłowego cyberbezpieczeństwa (cyber security industrial complex) ${ }^{28}$. Oba te twory są złożonymi strukturami socjotechnicznymi. Mają one także cechy zorganizowanych grup interesu. Warto wskazać na pewne ich podobieństwa i różnice. Klasyczny, zimnowojenny kompleks militarno-przemysłowy był bardzo scentralizowany, jego współczesny zaś cyfrowy odpowiednik cechuje raczej rozległa decentralizacja. Pierwszy miał także ekskluzywny charakter wejście we współpracę w jego ramach było ściśle kontrolowane i otoczone reżimem kontrwywiadowczym. Drugi jest bardziej inkluzyjny i bariera wejścia we współpracę jest tam bardziej elastyczna, ponieważ próbuje się przyciągać różne samorodne talenty technologiczne i naukowe ze świata cywilnego. Klasyczny kompleks militarno-przemysłowy miał dość jasno zdefiniowane granice, jego współczesna zaś odmiana ma formę bardziej amorficzną, hybrydalną ${ }^{29}$. Niezależnie od owych różnic strukturalnych warto podkreślić, że ciekawym podobieństwem obu kompleksów jest natomiast niechęć do bycia objętymi regulacjami ${ }^{30}$.

Wracając zaś do samego procesu wyścigu zbrojeń, ten klasyczny odbywał się $\mathrm{w}$ warunkach rywalizacji dwubiegunowej, przebiegającej na osi NATO-Układ Warszawski. Natomiast cyfrowy wyścig zbrojeń przebiega w warunkach rywalizacji bardziej wielobiegunowej. Jako głównych aktorów państwowych można wskazać: USA, Chiny, Rosję, Wielką Brytanię, Francję, Izrael, Japonię. Pozapaństwowi zaś aktorzy to przede wszystkim firmy bigtech: Google, Facebook, Amazon, Apple, Microsoft oraz w coraz większym stopniu ich odpowiedniki chińskie (Alibaba, Tencent, Baidu) i rosyjskie (grupa Yandex).

Zimnowojenny wyścig zbrojeń był jednym z głównych procesów cywilizacyjnych w XX wieku, ponieważ mógł doprowadzić do zagłady istotnej części cywilizacji, na przykład przez pełnowymiarowy konflikt nuklearny ${ }^{31}$. Ten ostatni przez tragiczne wydarzenia w Hiroszimie i Nagasaki oraz obrazowe, a przez to bardzo perswazyjne materiały wideo z prób nuklearnych łatwo było postrzegać jako poważne egzystencjalne zagrożenie dla istotnej części ludzkości.

W klasycznym kapitalizmie przemysłowym główną rolę odgrywał popyt ze strony wojska ${ }^{32}$. Odbywał się on w ramach standardowych (dla kultury militarnej) procedur poznawczych - można było policzyć czołgi i samoloty oraz przewidzieć

27 C.W. Mills, Elita władzy, Warszawa 1961.

28 D. Talbot, The Cyber Security Industrial Complex, „MIT Tech Review”, 6.12.2011, https:// www.technologyreview.com/s/426285/the-cyber-security-industrial-complex/ (dostęp: 1.09.2019); A. Ross, The Industries of the Future, London 2016, s. 146.

29 Zob. uwagi na temat hybryd i hybrydyzacji w analizach z zakresu bezpieczeństwa w M. Stochmal, J. Maciejewski, Hybrydyzacja obszarów badawczych środowiska (nie)bezpieczeństwa nie tylko w dyscyplinie socjologii, „Historia i Polityka” 23, 2018, s. 87-101.

30 S. Zuboff, op. cit., s. 63, 105.

31 K. Payne, Artificial Intelligence: A Revolution in Strategic Affairs?, „Survival” 2018, nr 5(60).

32 Ibidem, s. 121. 
konsekwencje użycia nowych rodzajów uzbrojenia (na przykład broni nuklearnej). Umożliwiało to postrzeganą jako racjonalną analizę procesu i pewną subiektywną jego przewidywalność. Symbolem tego typu radykalnej przewidywalności i racjonalności jest twórczość amerykańskiego teoretyka konfliktu militarnego Hermana Kahna ijego doktryna Drabiny eskalacji (ladder of escalation ${ }^{33}$. Rozważał on w niej „na chłodno” różne stopnie intensyfikacji konfliktu nuklearnego, co doprowadziło go do konkluzji, że konflikt nuklearny jest nieunikniony, ale także, jest (z punktu widzenia USA) do wygrania.

W przeciwieństwie do zimnowojennego współczesny cyfrowy wyścig zbrojeń jest w istotnym stopniu nieprzejrzysty ${ }^{34}$. Trudno mierzyć w nim postępy poszczególnych stron, stosując standardowe parametryzacje siły zbrojnej. Co więcej, wypracowywane w jego ramach potencjalnie przełomowe osiągnięcia (na przykład silna sztuczna inteligencja, funkcjonalny komputer kwantowy) mają trudno przewidywalne konsekwencje. Nieprzejrzysta jest także sama dynamika i struktura cyfrowego wyścigu - trudno wskazać granice podmiotów zaangażowanych w jego działanie, ponieważ większość technologii tworzonych w jego ramach jest w istocie technologiami „podwójnego zastosowania”, które mogą być zarówno użyte jako broń, jak i w celach cywilnych. Stąd w przeciwieństwie do na przykład broni nuklearnej cyfrowe technologie militarne, takie jak autonomiczne systemy bojowe, trudno jest poddać kontroli ${ }^{35}$.

Kluczowe znaczenie ma także fakt, że dynamika cyfrowego wyścigu zbrojeń ma bezprecedensowe przyspieszenie ${ }^{36}$. Innowacje są szybko wdrażane i służą do jeszcze szybszego opracowywania i wdrażania kolejnych innowacji.

W klasycznym wyścigu zbrojeń istotne znaczenie miała przewaga ilościowa $\mathrm{w}$ potencjale militarnym, liczona najpierw w dywizjach pancernych, później także w głowicach jądrowych. W cyfrowym wyścigu zbrojeń chodzi przede wszystkim o osiągnięcie jakościowej dominacji strategicznej. Obietnicą jest tu zyskanie znaczącej przewagi technologicznej, a przez to militarnej i ekonomicznej nad przeciwnikiem. Stawką jest dążenie do zapewnienia sobie bezpieczeństwa

${ }^{33}$ H. Kahn, On Escalation: Metaphors and Scenarios, New Brunswick 1965, s. 39.

34 D. Paletta, D. Yadron, J. Valentino-Devries, Cyberwar Ignites a New Arms Race, „The Wall Street Journal", 21.10.2015, http://www.wsj.com/articles/cyberwar-ignites-a-new-arms-race-14446 (dostęp: 10.09.2019).

35 Ch.A. Ford, The trouble with cyber arms control, „The New Atlantis” 2010, s. 52-67. Znany amerykański politolog Joseph S. Nye, twórca koncepcji soft power oraz były zastępca sekretarza obrony i przewodniczący Narodowej Rady Wywiadu Stanów Zjednoczonych, postuluje wprowadzenie przez społeczność międzynarodową sankcji dotyczących cyberbroni, podobnie jak ma to miejsce w wypadku zakazów dotyczących innych rodzajów broni masowego rażenia, na przykład broni biologicznej; zob. J.S. Nye, Joseph S. Nye: czekajac na globalna wojne w cyberprzestrzeni, „WP Opinie”, 23.3.2017, https://opinie.wp.pl/joseph-s-nye-czekajac-na-globalna-wojne-w-cyberprzestrzeni-6104126469960321a (dostęp: 1.10.2019).

36 J. Limnéll, The cyber arms race is accelerating-what are the consequences?, „Journal of Cyber Policy" 2016, nr 1, s. 50-60; M. Taddeo, L. Floridi, op. cit. 
także poprzez dominację nad innymi. W ostatecznej instancji chodzi o fizyczne przetrwanie. Ale problem w tym, że - jak wskazuje Zuboff oraz inni autorzy ${ }^{37}$ - konsekwencje opisywanej tu dynamiki mogą sprawić, że zniszczeniu ulegną dotychczasowe fundamenty cywilizacji współczesnej.

Zuboff wskazuje, że przemiany w ramach samego kapitalizmu pociągają za sobą zmiany metabolizmu ludzi i towarzyszy temu rewizja potrzeb i sposobów ich zaspokajania ${ }^{38}$. Przejściu od gospodarki w dominującym stopniu rolniczej do kapitalizmu przemysłowego towarzyszyły zmiany cyklu i stylu życia poszczególnych ludzi oraz całych społeczeństw. W gospodarce rolnej rytm pracy w ciągu doby czy roku wyznaczały naturalne cykle przyrody. W kapitalizmie przemysłowym rytm życia wyznaczały grafiki pracy i zegary. Praca na roli odciskała swoje piętno na organizmach pracujących. Podobnie przejście do kapitalizmu przemysłowego skutkowało pojawieniem się na masową skalę nowych chorób cywilizacyjnych, na przykład wad kręgosłupa spowodowanych siedzeniem na wyznaczonym miejscu pracy wiele godzin. Zdaniem Zuboff w kapitalizmie nadzoru ciała ludzi oraz funkcjonowanie ich organizmów podlegają podobnym zniekształceniom. Ciągłe korzystanie z technologii ekranowych odciska piętno na naszej postawie, powodując przykurcz mięśni szyi i charakterystyczne przygarbienie. Ślęczenie do późna w nocy ze smartfonem w ręku prowadzi do zaburzeń snu i zespołu nabytego deficytu koncentracji. Podstawowego charakteru w tym kontekście nabiera pytanie, jak na kondycję człowieka wpływają efekty właściwe cyfrowemu wyścigowi zbrojeń?

\section{Bezpieczeństwo ontologiczne}

Blok zachodni wygrał zimnowojenny wyścig zbrojeń głównie dlatego, że kapitalizm przemysłowy był bardziej wydajny i innowacyjny niż jego wschodnie alternatywy. Można przyjąć przez analogię, że źródłem przewag w cyfrowym wyścigu zbrojeń będzie ekspansja kapitalizmu nadzoru. Jeśli rację ma Zuboff w kwestii negatywnych konsekwencji oddziaływania kapitalizmu nadzoru na naturę ludzką, to uznać należy, że ta ostatnia może zostać poświęcona w imię uzyskania przewagi w ramach cyfrowego wyścigu zbrojeń.

Czyli dążąc do uzyskania bezpieczeństwa militarnego, nadwerężone zostałoby „bezpieczeństwo ontologiczne” ${ }^{\text {”. }}$. To ostatnie pojęcie ukuł A. Giddens ${ }^{40}$, wskazując na społeczną doniosłość podtrzymywania trwałości sensów i subiektywnego

37 A. Zybertowicz et al., Samobójstwo Oświecenia? Jak neuronauka i nowe technologie pustosza ludzki świat, Kraków 2016; H. Kissinger, How the Enlightenment Ends, „The Atlantic”, 1.06.2018, https://www.henryakissinger.com/articles/how-the-enlightenment-ends/ (dostęp: 1.09.2019).

38 Ibidem, s. 66.

39 K. Zybertowicz, A. Zybertowicz, Okiełznać zmianę. Bezpieczeństwo ontologiczne, rozwój technologiczny a kryzys Zachodu, „Filo-Sofija” 2017, nr 17(36).

40 A. Giddens, Nowoczesność i tożsamość, przeł. A. Szulżycka, Warszawa 2007, s. 50-78, 150-197.

Forum Socjologiczne 10, 2020

(C) for this edition by CNS 
poczucia uporządkowania i rozumienia rzeczywistości. Kluczową rolę odgrywa tu odtwarzanie pewnych podstawowych przekonań o człowieku i jego relacjach ze światem. Zdaniem Giddensa w wielu społecznościach tradycyjnych, mimo deficytów w zakresie zaspokajania podstawowych potrzeb, powszechnie inwestowano zasoby właśnie w instytucje podtrzymujące poczucie sensu, takie jak kościoły. Dla trwania danej społeczności istotne znaczenie ma subiektywne przekonanie jej mieszkańców na temat trwałości i sensowności świata, w którym funkcjonują. Przekonanie to może być w różnej relacji względem rzeczywistego poziomu zagrożeń dla danej społeczności.

\section{Podsumowanie - bezpieczeństwo ontologiczne ofiarą kapitalizmu nadzoru i cyfrowego wyścigu zbrojeń}

W tym kontekście obserwowana w ostatnich latach wzbierająca fala różnych radykalizmów ideologicznych jawi się właśnie jako pewna uporczywa próba ratowania bezpieczeństwa ontologicznego kosztem innych obszarów zastanego ładu instytucjonalnego. Wszak nic tak nie wzmacnia tożsamości i solidarności jak krwawy konflikt i wojna ${ }^{41}$. Paradoksalnie dążenie do konfliktu, pociągając za sobą ryzyko narażenia danej społeczności na fizyczne niebezpieczeństwo, może mieć funkcję ukrytą, która sprowadza się do odbudowy bezpieczeństwa ontologicznego. Nawet gdy jakiejś zbiorowości grozi egzystencjalne niebezpieczeństwo, ale jest ono „oswojone” przez jego kulturowe zdefiniowanie jako coś znanego, naturalnego, normalnego, wtedy jej bezpieczeństwo ontologiczne nie podlega nadwerężeniu. Przeciwna sytuacja ma miejsce w przypadku zbiorowości, której biologicznemu przetrwaniu zasadniczo nic poważnego nie zagraża, ale która traci poczucie rozumienia świata, w którym funkcjonuje, i która jest zaskakiwana kolejnymi nieprzewidzianymi zjawiskami, jawiącymi się jako symptomy nadciągającego kryzysu. Rozprzestrzeniający się kapitalizm nadzoru i przybierający na sile cyfrowy wyścig zbrojeń sprawiają, że w coraz większym stopniu społeczeństwa współczesne doświadczają stanu podobnego do drugiego z wymienionych przypadków.

Cyfrowy wyścig zbrojeń sprzężony z systemem kapitalizmu nadzoru jawi się tutaj jako proces, który na poziomie deklaracji ma prowadzić do postępu cywilizacyjnego i zapewnienia bezpieczeństwa, faktycznie jednak prowadzi także do nowych rodzajów destabilizacji, godząc w podstawy nie tylko porządku międzynarodowego, lecz także cywilizacji współczesnej. Tak jak zimnej wojnie towarzyszyła groźba destrukcji rdzenia cywilizacji wskutek pełnowymiarowego konfliktu nuklearnego, tak samo współczesny cyfrowy wyścig zbrojeń może być równie niszczący. Tyle że symptomy eskalacji konfliktu będą tu o wiele trudniejsze do określenia i zaobserwowania.

41 B. Ehrenreich, Rytuały krwi. Namiętność do wojny, geneza i historia, Warszawa 2001. 


\section{Bibliografia}

Craig A., Valeriano B., Conceptualising cyber arms races, 8th International Conference on Cyber Conflict (CyCon), 2016, https://ieeexplore.ieee.org/abstract/document/7529432 (dostęp: 12.04.2019).

Ehrenreich B., Rytuały krwi. Namiętność do wojny, geneza i historia, przeł. P. Kołyszko, Warszawa 2001. Ford Ch.A., The trouble with cyber arms control, „The New Atlantis” 2010.

Giddens A., Nowoczesność i tożsamość, przeł. A. Szulżycka, Warszawa 2007.

Gurtowski M., Waszewski J., Prejudices behind Algorithms: Automated Surveillance Systems as Tools of Segregation and Discrimination, „Kultura i Edukacja” 4, 2018.

Kahn H., On Escalation: Metaphors and Scenarios, New Brunswick 1965.

Kissinger H., How the Enlightenment Ends, „The Atlantic”, 1.06.2018, https://www.henryakissinger. com/articles/how-the-enlightenment-ends/ (dostęp: 1.09.2019).

Konecki K., Studia z metodologii badań jakościowych. Teoria ugruntowana, Warszawa 2000.

Limnéll J., The cyber arms race is accelerating — what are the consequences?, „Journal of Cyber Policy” 2016, $\mathrm{nr} 1$.

Mills C.W., Elita władzy, przeł. I. Rafelski, Warszawa 1961.

Morozov E., Capitalism's New Clothes, „The Baffler” 2019, https://thebaffler.com/latest/capitalisms-new-clothes-morozov (dostęp: 1.09.2019).

Nye J.S., Joseph S. Nye: czekając na globalna wojne w cyberprzestrzeni, „WP Opinie”, 23.3.2017, https:// opinie.wp.pl/joseph-s-nye-czekajac-na-globalna-wojne-w-cyberprzestrzeni-6104126469960321a (dostęp: 1.10.2019).

Payne K., Artificial Intelligence: A Revolution in Strategic Affairs?, „Survival” 2018, nr 5(60).

Ross A., The Industries of the Future, London 2016.

Sarnacka-Mahoney E., Kapitalizm inwigilacji. Nasze zachowanie jest już nie tylko śledzone, ale też zmienia-ne w określonym kierunku. Wywiad z Shoshanq Zuboff, 7.07.2018, https://forsal.pl/ artykuly/1164703,kapitalizm-inwigilacji-nasze-zachowanie-jest-juz-nie-tylko-sledzone-ale-tez-zmieniane-w-okreslonym-kierunku-wywiad.html (dostęp: 12.04.2019).

Stochmal M., Maciejewski J., Hybrydyzacja obszarów badawczych środowiska (nie)bezpieczeństwa nie tylko $w$ dyscyplinie socjologii, „Historia i Polityka” 23, 2018, s. 87-101.

Taddeo M., Floridi L., Regulate artificial intelligence to avert cyber arms race, „Nature” 16.04.2019, s. 296, https://www.nature.com/articles/d41586-018-04602-6?platform=hootsuite (dostęp: 12.04.2019).

Talbot D., The Cyber Security Industrial Complex, „MIT Tech Review”, 6.12.2011, https://www.technologyreview.com/s/426285/the-cyber-security-industrial-complex/ (dostęp: 1.09.2019).

Tzu S., Sztuka wojny, przeł. J. Zawadzki, Warszawa 2009.

Waszewski J., Gurtowski M., Cyfrowy rasizm? Zautomatyzowane techniki nadzoru jako narzędzie segregacji i dyskryminacji, „Transformacje” 2015, nr 1/2.

Zuboff S., The Age of Surveillance Capitalism. The Fight for the Future at the New Frontier of Power, London 2019.

Zybertowicz A., Gurtowski M., Tamborska K., Trawiński M., Waszewski J., Samobójstwo Oświecenia? Jak neuronauka i nowe technologie pustosza ludzki świat, Kraków 2016.

Zybertowicz K., Zybertowicz A., Okiełznać zmianę. Bezpieczeństwo ontologiczne, rozwój technologiczny a kryzys Zachodu, „Filo-Sofija” 2017, nr 17(36).

Forum Socjologiczne 10, 2020

(C) for this edition by CNS 


\section{The Digital Arms Race in the Age of Surveillance Capitalism}

\section{Summary}

American social psychologist Shoshana Zuboff describes and presents in her recent book "The Age of Surveillance Capitalism" the theory that explains changes of contemporary capitalism. She calls it "surveillance capitalism" and indicates its crucial role in transformations of social control systems. The aim of this paper is to consider the relationship between "surveillance capitalism" and the global security landscape. We will consider the hypothesis that "surveillance capitalism" is a accelerator of a modern cyber arms race, similar to classic industrial capitalism as in the case of the Cold War arms race.

Keywords: crisis, military security, ontological security, cyber arms race, surveillance capitalism, industrial capitalism, human person, military-industrial complex 